\title{
Gas exchanges and growth of passion fruit seedlings under salt stress and hydrogen peroxide ${ }^{1}$
}

\author{
André Alisson Rodrigues da Silva ${ }^{2}$, Geovani Soares de Lima ${ }^{3}$, \\ Carlos Alberto Vieira de Azevedo ${ }^{2}$, Hans Raj Gheyi ${ }^{4}$, Leandro de Pádua Souza ${ }^{2}$, Luana Lucas de Sá Almeida Veloso ${ }^{2}$
}

\section{ABSTRACT}

The semi-arid region of the Brazilian Northeast has adequate edaphoclimatic conditions for the passion fruit production, but the water used for irrigation commonly has high concentrations of salts that are harmful to the plant growth and development. A previous supply of hydrogen peroxide induces the acclimation of plants under saline stress conditions, reducing deleterious effects on their growth and physiology. This study aimed to evaluate the gas exchanges and growth of passion fruit as a function of irrigation with saline water and exogenous application of hydrogen peroxide. The experiment was carried out under greenhouse conditions, using a randomized block design, in a 4 x 4 factorial arrangement, being four levels of irrigation water electrical conductivity $\left(0.7 \mathrm{dS} \mathrm{m}^{-1}\right.$, $1.4 \mathrm{dS} \mathrm{m}^{-1}, 2.1 \mathrm{dS} \mathrm{m}^{-1}$ and $\left.2.8 \mathrm{dS} \mathrm{m}^{-1}\right)$ and four hydrogen peroxide concentrations $(0 \mu \mathrm{M}, 25 \mu \mathrm{M}, 50 \mu \mathrm{M}$ and $75 \mu \mathrm{M})$, with four replicates and two plants per plot. The hydrogen peroxide application attenuated the deleterious effects of the irrigation water salinity on transpiration, $\mathrm{CO}_{2}$ assimilation rate, internal carbon concentration, plant height and leaf area of yellow passion fruit, at 60 days after sowing, with the concentration of $25 \mu \mathrm{M}$ being the most efficient. Irrigation using water with electrical conductivity above $0.7 \mathrm{dS} \mathrm{m}^{-1}$ negatively affects the gas exchanges and growth of passion fruit, being the stomatal conductance and leaf area the most sensitive variables to the salt stress.

KEYWORDS: Passiflora edulis F. flavicarpa, saline water, acclimation.

\section{INTRODUCTION}

Passion fruit (Passiflora edulis f. flavicarpa) is part of a group of fruit crops that has economic importance to Brazil, especially to the Northeast

\section{RESUMO}

Trocas gasosas e crescimento de mudas de maracujazeiro sob estresse salino e peróxido de hidrogênio

A região semiárida do Nordeste brasileiro apresenta condições edafoclimáticas adequadas à produção do maracujazeiro, mas a água utilizada na irrigação, comumente, possui altas concentrações de sais, que são prejudiciais ao crescimento e desenvolvimento das plantas. O fornecimento prévio de peróxido de hidrogênio induz a aclimatação das plantas sob condições de estresse salino, reduzindo os efeitos deletérios sobre o seu crescimento e fisiologia. Objetivou-se avaliar as trocas gasosas e o crescimento do maracujazeiro, em função da irrigação com águas salinas e aplicação exógena de peróxido de hidrogênio. O estudo foi conduzido em casade-vegetação, utilizando-se delineamento de blocos casualizados, em arranjo fatorial $4 \times 4$, sendo quatro níveis de condutividade elétrica da água de irrigação $\left(0,7 \mathrm{dS} \mathrm{m}^{-1} ; 1,4 \mathrm{dS} \mathrm{m}^{-1} ; 2,1 \mathrm{dS} \mathrm{m}^{-1}\right.$; e $2,8 \mathrm{dS} \mathrm{m}^{-1}$ ) e quatro concentrações de peróxido de hidrogênio $(0 \mu \mathrm{M}, 25 \mu \mathrm{M}, 50 \mu \mathrm{M}$ e $75 \mu \mathrm{M})$, com quatro repetições e duas plantas por parcela. A aplicação de peróxido de hidrogênio atenuou os efeitos deletérios da salinidade da água de irrigação sobre a transpiração, taxa de assimilação de $\mathrm{CO}_{2}$, concentração interna de carbono, altura de planta e área foliar do maracujazeiro amarelo, aos 60 dias após a semeadura, sendo a concentração de $25 \mu \mathrm{M}$ a mais eficiente. A irrigação com água de condutividade elétrica acima de $0,7 \mathrm{dS} \mathrm{m}^{-1}$ afeta negativamente as trocas gasosas e o crescimento do maracujazeiro, sendo a condutância estomática e a área foliar as variáveis mais sensíveis ao estresse salino.

PALAVRAS-CHAVE: Passiflora edulis f. flavicarpa, águas salinas, aclimatação.

region, responsible for $60.92 \%$ of the national production (IBGE 2017). Brazil is the world's largest producer and consumer of yellow passion fruit and its agroindustry is responsible for the third most produced juice in the country (Freire et al. 2014).

1. Received: Oct. 31, 2018. Accepted: May 03, 2019. Published: Oct. 15, 2019. DOI: 10.1590/1983-40632019v4955671.

2. Universidade Federal de Campina Grande, Campina Grande, PB, Brasil._E-mail/ORCID: andrealisson_cgpb@hotmail.com/ 0000-0001-9453-1192, cvieiradeazevedo@gmail.com/0000-0001-7336-1243, engenheiropadua@hotmail.com/ 0000-0001-7588-2413, luana_lucas_15@hotmail.com/0000-0003-0537-7985.

3. Universidade Federal de Campina Grande, Unidade Acadêmica de Ciências Agrárias, Pombal, PB, Brasil. E-mail/ORCID: geovani.soares@pq.cnpq.br/0000-0001-9960-1858.

4. Universidade Federal do Recôncavo da Bahia, Núcleo de Engenharia de Água e Solo, Cruz das Almas, BA, Brasil. E-mail/ORCID: hans@pq.cnpq.br/0000-0002-1066-0315. 
The semi-arid region of northeastern Brazil, despite providing adequate edaphoclimatic conditions for the passion fruit production, does not meet the water requirements of this crop for cultivation on a commercial scale due to the water restriction, in terms of quantity and quality, making the crop dependent on irrigation, in many cases cultivated using water with a high salt content, which can induce physiological modifications such as the reduction of stomatal conductance and $\mathrm{CO}_{2}$ assimilation rate, thus compromising the plant growth and development (Cavalcante et al. 2011).

The passion fruit cultivation in the semi-arid region of the Brazilian Northeast can be optimized using techniques that allow the management of saline soil and/or saline water in agriculture. Among these alternatives, the exogenous application of hydrogen peroxide $\left(\mathrm{H}_{2} \mathrm{O}_{2}\right)$ has shown to be promising in mitigating the effects caused by salt stress on crops (Carvalho et al. 2011, Gondim et al. 2011, Oliveira 2016).

The exogenous application of hydrogen peroxide by spraying and/or pre-treatment of seeds at low concentrations promotes a moderate stress condition, which results in the accumulation of latent signals in different parts of the plant. Thus, when a more severe stress condition occurs, the stored signals will lead to molecular adjustments, resulting in acclimation mechanisms, especially in glycophytes plants (Savvides et al. 2016).

Hydrogen peroxide can stimulate a greater accumulation of proteins and soluble carbohydrates, which will act as organic solutes, assisting in the osmotic adjustment of plants to the salt stress conditions, allowing a higher absorption of water and nutrients (Carvalho et al. 2011). It is noteworthy that there is no information on the commercial use of hydrogen peroxide in agriculture; so far, the use of hydrogen peroxide has been only at the research level.

In this context, this study aimed to evaluate the gas exchanges and growth of yellow passion fruit seedlings, as a function of irrigation water salinity and exogenous application of hydrogen peroxide, through seed imbibition and foliar spraying.

\section{MATERIAL AND METHODS}

The study was conducted from June to August 2017 , in polypropylene pots $\left(\right.$ Citropote $^{\circledR}$ ) with volume of $8 \mathrm{dm}^{3}$, under greenhouse conditions, at the Universidade Federal de Campina Grande, in Campina Grande, Paraíba state, Brazil ( $7^{\circ} 15^{\prime} 18^{\prime \prime S}$, $35^{\circ} 52^{\prime} 28^{\prime \prime} \mathrm{W}$ and mean altitude of $550 \mathrm{~m}$ ).

The experiment used seeds of yellow passion fruit (Passiflora edulis Sims) collected from fruits of a commercial orchard located in Nova Floresta (Paraíba state, Brazil) and obtained from plants subjected to mass selection, with standardization based on plant vigor and sanitary conditions. This genotype is popularly known as 'Guinezinho', due to the spots on the rind similar to those existing on the feathers of a bird locally known as 'galinha Guiné' (Helmeted guineafowl - Numida meleagris) (Medeiros et al. 2016).

Treatments resulted from the combination of two factors: four levels of irrigation water electrical conductivity - $\mathrm{ECw}\left(0.7 \mathrm{dS} \mathrm{m}^{-1}, 1.4 \mathrm{dS} \mathrm{m}^{-1}, 2.1 \mathrm{dS} \mathrm{m}^{-1}\right.$ and $2.8 \mathrm{dS} \mathrm{m}^{-1}$ ) associated with four concentrations of hydrogen peroxide $-\mathrm{H}_{2} \mathrm{O}_{2}(0 \mu \mathrm{M}, 25 \mu \mathrm{M}, 50 \mu \mathrm{M}$ and $75 \mu \mathrm{M})$, distributed in a randomized block design, in a $4 \times 4$ factorial arrangement, with four replicates, totaling 64 experimental units.

The levels of $1.4 \mathrm{dS} \mathrm{m}^{-1}, 2.1 \mathrm{dS} \mathrm{m}^{-1}$ and $2.8 \mathrm{dS} \mathrm{m}^{-1}$ were prepared by dissolving the salts $\mathrm{NaCl}, \mathrm{CaCl}_{2} \cdot 2 \mathrm{H}_{2} \mathrm{O}$ and $\mathrm{MgCl}_{2} \cdot 6 \mathrm{H}_{2} \mathrm{O}$, in equivalent proportions of $7: 2: 1$, respectively, in water from the local supply $\left(\mathrm{ECW}=1.10 \mathrm{dS} \mathrm{m}^{-1}\right)$. This proportion of salts is commonly found in sources of water used for irrigation in small properties of the Brazilian Northeast (Medeiros 1992), based on the relationship between $\mathrm{ECW}$ and the concentration of salts $\left(\mathrm{mmol}_{\mathrm{c}} \mathrm{L}^{-1}=10 * \mathrm{ECw} \mathrm{dS} \mathrm{m}{ }^{-1}\right)$ (Rhoades et al. 2000). The level of $0.7 \mathrm{dS} \mathrm{m}^{-1}$ was obtained by diluting water from the local supply in rainwater $\left(\mathrm{ECw}=0.02 \mathrm{dS} \mathrm{m}^{1}\right)$.

The pots were filled with $6.0 \mathrm{~kg}$ of a dry substrate consisting of soil (84\%), sand (15\%) and humus $(1 \%)$, on a mass basis. The soil used in the experiment was classified as a sandy loam Entisol, collected at the $0-20 \mathrm{~cm}$ layer, in the rural area of Lagoa Seca (Paraíba state, Brazil), which was properly pounded to break up clods and sieved. Its physical and chemical characteristics were determined according to Teixeira et al. (2017): $\mathrm{Ca}^{2+}=2.60 \mathrm{cmol} \mathrm{kg}^{-1}$; $\mathrm{Mg}^{2+}=3.66 \mathrm{cmol}_{\mathrm{c}} \mathrm{kg}^{-1} ; \mathrm{Na}^{+}=0.16 \mathrm{cmol}_{\mathrm{c}} \mathrm{kg}^{-1}$; $\mathrm{K}^{+}=0.22 \mathrm{cmol}_{\mathrm{c}} \mathrm{kg}^{-1} ; \mathrm{Al}^{3+}+\mathrm{H}^{+}=1.93 \mathrm{cmol}_{\mathrm{c}} \mathrm{kg}^{-1}$; $\mathrm{pH}(1: 2.5$ soil water suspension $)=5.9 ; \mathrm{ECse}=$ $1.0 \mathrm{dS} \mathrm{m}^{-1}$; organic matter $=1.36 \mathrm{dag} \mathrm{kg}^{-1}$; sand $=$ $732.9 \mathrm{~g} \mathrm{~kg}^{-1}$; silt $=142.1 \mathrm{~g} \mathrm{~kg}^{-1}$; clay $=125.0 \mathrm{~g} \mathrm{~kg}^{-1}$; 
bulk density $=1.39 \mathrm{~kg} \mathrm{dm}^{-3}$; moisture content at $33.42 \mathrm{kPa}=11.98 \mathrm{dag} \mathrm{kg}^{-1}$ and at $1,519.5 \mathrm{kPa}=$ $4.32 \mathrm{dag} \mathrm{kg}^{-1}$.

Before sowing, the soil moisture content was raised up to the field capacity, using the respective water of each treatment. After sowing, irrigation was performed daily by applying, in each pot, a volume of water sufficient to maintain the soil moisture close to the field capacity. The volume applied was determined according to the water requirement of the plants, estimated by the water balance at intervals of 15 days, by subtracting the volume drained from the volume applied in the irrigation during this period. To avoid an excessive accumulation of salts in the root zone, a leaching fraction equivalent to 0.10 was applied at intervals of 15 days, which also permitted to estimate the plant water requirement in each treatment.

The hydrogen peroxide $\left(\mathrm{H}_{2} \mathrm{O}_{2}\right)$ concentrations were established according to a previous study conducted by Panngom et al. (2018), with dilution in deionized water. The seeds underwent a pre-treatment with $\mathrm{H}_{2} \mathrm{O}_{2}$, in which they were soaked in solutions with the concentrations of the respective treatments, for a period of $24 \mathrm{~h}$. Seeds of the control treatment $(0 \mu \mathrm{M})$ were soaked in distilled water for the same period. Sowing was carried out after the previously described treatment, by equidistantly planting five seeds at a $3 \mathrm{~cm}$ depth. At 20 days after the emergence, thinning was performed to leave only one plant per pot, by selecting the one with the best vigor.

Top-dressing fertilization with nitrogen, potassium and phosphorus was performed based on the recommendation of Novais et al. (1991), applying $1.33 \mathrm{~g}$ of urea, $1.5 \mathrm{~g}$ of potassium chloride and $3.6 \mathrm{~g}$ of monoammonium phosphate, equivalent to $100 \mathrm{mg} \mathrm{kg}^{-1}, 150 \mathrm{mg} \mathrm{kg}^{-1}$ and $300 \mathrm{mg} \mathrm{kg}^{-1}$ of the substrate for $\mathrm{N}, \mathrm{K}_{2} \mathrm{O}$ and $\mathrm{P}_{2} \mathrm{O}_{5}$, respectively, in four applications via fertigation, at 15-day intervals, with the first one at 15 days after sowing (DAS). To meet the requirement of the micronutrients, the plants were sprayed with a nutrient solution containing $2.5 \mathrm{~g} \mathrm{~L}^{-1}$ of a commercial product with the following composition: $\mathrm{N}(15 \%) ; \mathrm{P}_{2} \mathrm{O}_{5}(15 \%) ; \mathrm{K}_{2} \mathrm{O}(15 \%)$; $\mathrm{Ca}(1 \%) ; \mathrm{Mg}(1.4 \%) ; \mathrm{S}(2.7 \%)$; Zn (0.5\%); B (0.05\%); Fe (0.5\%); Mn (0.05\%); Cu (0.5\%) and Mo $(0.02 \%)$, at 30 and 45 DAS. At 30, 45 and 60 DAS, leaves were manually sprayed (adaxial and abaxial sides) between 05:00 p.m. and 05:30 p.m., with the respective solutions of hydrogen peroxide.
The treatment effects on passion fruit seedlings were determined through gas exchanges [stomatal conductance (gs), transpiration (E), $\mathrm{CO}_{2}$ assimilation rate (A), internal $\mathrm{CO}_{2}$ concentration (Ci), instantaneous carboxylation efficiency and instantaneous water-use efficiency] and through the growth variables plant height, stem diameter, number of leaves and leaf area.

Gas exchanges were measured at 60 DAS. The stomatal conductance $\left(\mathrm{mol} \mathrm{m} \mathrm{m}^{-2} \mathrm{~s}^{-1}\right.$ of $\left.\mathrm{H}_{2} \mathrm{O}\right)$, transpiration $\left(\mathrm{mmol} \mathrm{m}^{-2} \mathrm{~s}^{-1}\right.$ of $\left.\mathrm{H}_{2} \mathrm{O}\right), \mathrm{CO}_{2}$ assimilation rate $\left(\mu \mathrm{mol} \mathrm{m} \mathrm{m}^{-2} \mathrm{~s}^{-1}\right)$ and internal $\mathrm{CO}_{2}$ concentration $\left(\mu \mathrm{mol} \mathrm{m} \mathrm{m}^{-2} \mathrm{~s}^{-1}\right)$ were evaluated on the third fully expanded leaf, counted from the apex, using a portable gas exchange meter "LCPro+" (ADC BioScientific Ltda.). These data were used to quantify the instantaneous water-use efficiency (WUEi) $(\mathrm{A} / \mathrm{E})\left[\left(\mu \mathrm{mol} \mathrm{m} \mathrm{m}^{-2} \mathrm{~s}^{-1}\right)\left(\mathrm{mol} \mathrm{m} \mathrm{m}^{-2} \mathrm{~s}^{-1} \text { of } \mathrm{H}_{2} \mathrm{O}\right)^{-1}\right]$ and instantaneous carboxylation efficiency (CEi) (A/Ci)

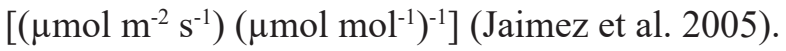

The passion fruit seedlings growth was measured at 45 and 60 DAS. Plant height $(\mathrm{cm})$ was measured taking as a reference the distance from the collar to the apical meristem; stem diameter ( $\mathrm{mm}$ ) at $2 \mathrm{~cm}$ above the collar; and the number of leaves was obtained by counting the fully expanded leaves with a minimum length of more than $3 \mathrm{~cm}$ in each plant. The leaf area - LA $\left(\mathrm{cm}^{2}\right)$ was determined as recommended by Cavalcante et al. (2002), considering the equation: $\mathrm{LA}=0.78 \mathrm{X}$, where, besides the mathematical constant $(0.78)$ defined by the authors, $X$ is the product of the length by width $(\mathrm{cm})$.

For each measured variable, the data were subjected to analysis of variance by the F-test at $5 \%$ of significance. For variables with significant treatment effects, regression analyses were carried out and polynomial models up to the second order were adjusted, using the Sisvar software (Ferreira 2014). For fitting the response surface models, the TableCurve 3D software was used.

\section{RESULTS AND DISCUSSION}

Based on the summary of the F-test (Table 1), the levels of irrigation water salinity significantly affected the stomatal conductance, transpiration, $\mathrm{CO}_{2}$ assimilation rate, internal $\mathrm{CO}_{2}$ concentration, instantaneous carboxylation efficiency and instantaneous water-use efficiency. The concentrations of hydrogen peroxide alone did not influence any 
Table 1. Summary of the F-test significance ${ }^{1}$ in the analyses of variance for stomatal conductance (gs), transpiration $(\mathrm{E}), \mathrm{CO}_{2}$ assimilation rate $(\mathrm{A})$, internal $\mathrm{CO}_{2}$ concentration $(\mathrm{Ci})$, instantaneous carboxylation efficiency (CEi) and instantaneous water-use efficiency (WUEi) of yellow passion fruit plants grown from seeds treated with hydrogen peroxide and irrigated with waters of different salt concentrations, evaluated at 60 days after sowing.

\begin{tabular}{|c|c|c|c|c|c|c|}
\hline \multirow{2}{*}{ Source of variation } & \multicolumn{6}{|c|}{ F-test } \\
\hline & gs & $\mathrm{E}$ & $\mathrm{A}$ & $\mathrm{Ci}$ & $\mathrm{CEi}$ & WUEi \\
\hline Salinity levels (SL) & $* *$ & $* *$ & $* *$ & $*$ & $* *$ & $* *$ \\
\hline Linear regression & $* *$ & $* *$ & $* *$ & $* *$ & $* *$ & $* *$ \\
\hline Quadratic regression & ns & ns & ns & ns & $*$ & ns \\
\hline Hydrogen peroxide $\left(\mathrm{H}_{2} \mathrm{O}_{2}\right)$ & ns & ns & ns & ns & ns & ns \\
\hline Linear regression & ns & ns & ns & ns & ns & ns \\
\hline Quadratic regression & ns & $\mathrm{ns}$ & ns & ns & ns & $\mathrm{ns}$ \\
\hline Interaction $\mathrm{SL} \times \mathrm{H}_{2} \mathrm{O}_{2}$ & ns & $*$ & $* *$ & $* *$ & ns & ns \\
\hline Blocks & ns & ns & ns & ns & ns & ns \\
\hline $\mathrm{CV}(\%)$ & 19.1 & 16.6 & 10.6 & 12.4 & 18.3 & 18.9 \\
\hline
\end{tabular}

ns, $*$ and $* *$ : not significant $(\mathrm{p}>0.05)$, significant $(\mathrm{p}<0.05)$ and highly significant $(\mathrm{p}<0.01)$, respectively.

of the studied variables. However, the interaction between salinity levels and hydrogen peroxide concentrations was significant for transpiration, $\mathrm{CO}_{2}$ assimilation rate and internal $\mathrm{CO}_{2}$ concentration.

The increase in the irrigation water electrical conductivity negatively affected the stomatal conductance of passion fruit plants and, according to the regression equation (Figure 1), there was a linear and decreasing effect with the reduction of about $20.6 \%$ per unit increment in the $\mathrm{ECW}$. In relative terms, a comparison between the results obtained in plants subjected to the highest salinity level $\left(2.8 \mathrm{dS} \mathrm{m}^{-1}\right)$ and those obtained at the lowest level $\left(0.7 \mathrm{dS} \mathrm{m}^{-1}\right)$ showed a reduction in stomatal conductance of $50 \%\left(0.108 \mathrm{~mol} \mathrm{~m}^{-2} \mathrm{~s}^{-1}\right.$ of $\left.\mathrm{H}_{2} \mathrm{O}\right)$. Stomatal closure is one of the main mechanisms

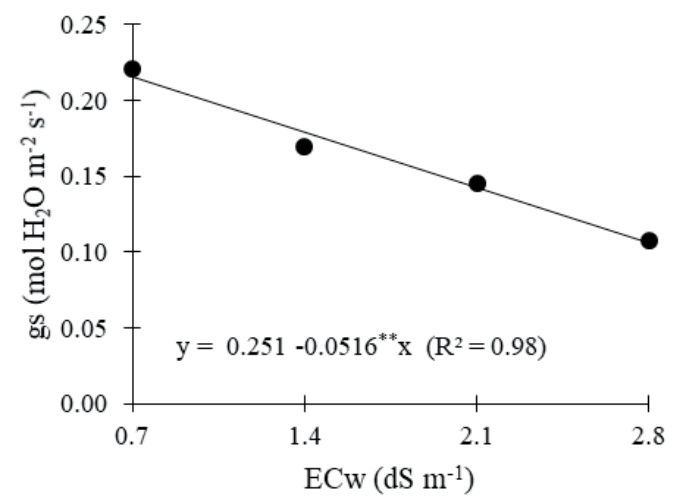

Figure 1. Stomatal conductance (gs) of yellow passion fruit plants, as a function of irrigation water salinity $(\mathrm{ECw})$, at 60 days after sowing. ${ }^{* *}$ Significant value at $1 \%$ of probability. for reducing the water loss in plants under salt stress (Lima et al. 2014). Moreover, stomatal closure restricts the $\mathrm{CO}_{2}$ entry in the leaf mesophyll cells, what may increase the susceptibility to photochemical damage, because the reduction in the $\mathrm{CO}_{2}$ assimilation rate causes an excessive light energy in the photosystem II (Munns \& Tester 2008).

The analysis of the interaction between the irrigation water salinity and hydrogen peroxide concentrations (Figure 2A) revealed that the highest transpiration value $\left(2.20 \mathrm{mmol} \mathrm{m}^{-2} \mathrm{~s}^{-1}\right.$ of $\left.\mathrm{H}_{2} \mathrm{O}\right)$ was obtained in plants irrigated with $1.4 \mathrm{dS} \mathrm{m}^{-1}$ of water and treated with $25 \mu \mathrm{M}$ of $\mathrm{H}_{2} \mathrm{O}_{2}$. However, there was a decrease in the transpiration when $\mathrm{H}_{2} \mathrm{O}_{2}$ concentrations above $25 \mu \mathrm{M}$ were used, regardless of the electrical conductivity of the irrigation water. The lowest transpiration $\left(1.42 \mathrm{mmol} \mathrm{m}^{-2} \mathrm{~s}^{-1}\right.$ of $\left.\mathrm{H}_{2} \mathrm{O}\right)$ was observed in plants irrigated with $2.8 \mathrm{dS} \mathrm{m}^{-1}$ and subjected to a concentration of $75 \mu \mathrm{M}$ of $\mathrm{H}_{2} \mathrm{O}_{2}$, corresponding to a reduction of $35.45 \%\left(0.78 \mathrm{mmol} \mathrm{m}^{-2} \mathrm{~s}^{-1}\right.$ of $\left.\mathrm{H}_{2} \mathrm{O}\right)$, in comparison to plants with a higher transpiration.

The reduction in the transpiration with the increase in the irrigation water electrical conductivity observed in plants that were treated with $\mathrm{H}_{2} \mathrm{O}_{2}$ above $25 \mu \mathrm{M}$ is a mechanism that enables the plant to reduce the water loss to the atmosphere, since the transpiration rate, in this case, is greater than the water absorption rate from the soil, due to the osmotic effect (Larcher 2006). On the other hand, the increase in transpiration observed particularly at the concentration of $25 \mu \mathrm{M}$, even with an increase of the electrical conductivity, probably resulted from the beneficial effect promoted by the $\mathrm{H}_{2} \mathrm{O}_{2}$ at low 

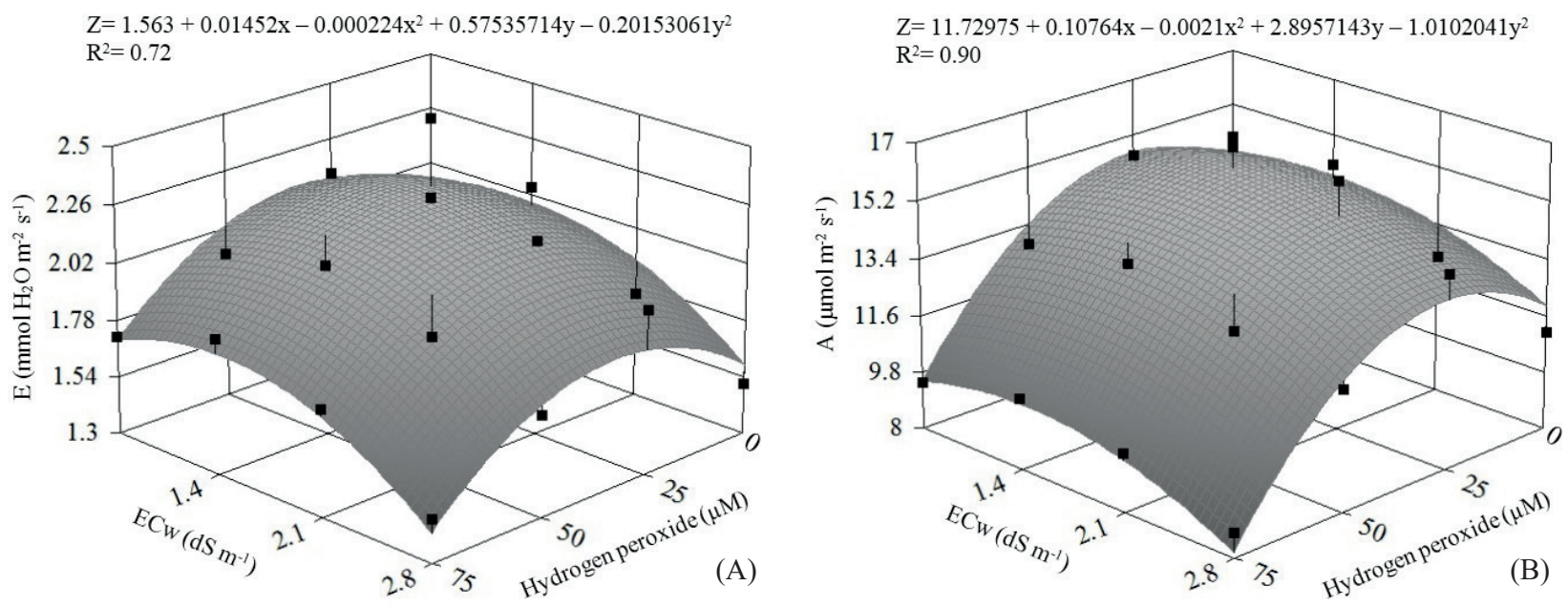

Figure 2. Transpiration rate - E (A) and $\mathrm{CO}_{2}$ assimilation rate - A (B) of yellow passion fruit plants grown from seeds treated with different concentrations of hydrogen peroxide $\left(\mathrm{H}_{2} \mathrm{O}_{2}\right)$ and levels of irrigation water salinity (ECw), evaluated at 60 days after sowing ( $\mathrm{x}$ and $\mathrm{y}$ are the concentrations of $\mathrm{H}_{2} \mathrm{O}_{2}$ and $\mathrm{ECw}$, respectively).

concentrations, which may be associated with its role as a signaling molecule, acting in the regulation of various mechanisms, including responses to salt stress (Baxter et al. 2014). In addition, hydrogen peroxide, when applied at low concentrations in plants, induces the defense system of antioxidant enzymes, which acts by reducing the deleterious effects of salinity (Carvalho et al. 2011).

The $\mathrm{CO}_{2}$ assimilation rate was also significantly affected by the interaction between irrigation water salinity and hydrogen peroxide concentration. According to the regression equation (Figure 2B), it was verified that the plants submitted to $25 \mu \mathrm{M}$ of $\mathrm{H}_{2} \mathrm{O}_{2}$ and irrigated with $1.4 \mathrm{dS} \mathrm{m}^{-1}$ of water achieved the highest rate of $\mathrm{CO}_{2}$ assimilation $\left(15.18 \mu \mathrm{mol} \mathrm{m} \mathrm{m}^{-2} \mathrm{~s}^{-1}\right)$. However, the lowest $\mathrm{CO}_{2}$ assimilation rate $\left(8.18 \mu \mathrm{mol} \mathrm{m} \mathrm{m}^{-2} \mathrm{~s}^{-1}\right)$ was obtained in plants submitted to $75 \mu \mathrm{M}$ of $\mathrm{H}_{2} \mathrm{O}_{2}$ and irrigated with $2.8 \mathrm{dS} \mathrm{m}^{-1}$ of water, corresponding to a reduction of $46.11 \%\left(7.0 \mu \mathrm{mol} \mathrm{m}^{-2} \mathrm{~s}^{-1}\right)$, when compared to plants with a higher assimilation rate. Hence, it can be inferred that the excess of reactive oxygen species exerts a negative effect, mainly caused by oxidative stress, in the plant metabolism.

The interaction between the factors (salinity levels $\mathrm{x}_{2} \mathrm{O}_{2}$ ) had a significant effect on the passion fruit internal $\mathrm{CO}_{2}$ concentration at 60 DAS. Based on the regression equation (Figure $3 \mathrm{~A}$ ), it was found that the highest internal $\mathrm{CO}_{2}$ concentration $\left(229.02 \mu \mathrm{mol} \mathrm{m}^{-2} \mathrm{~s}^{-1}\right)$ was obtained in plants submitted to $25 \mu \mathrm{M}$ of $\mathrm{H}_{2} \mathrm{O}_{2}$ and irrigated with $1.4 \mathrm{dS} \mathrm{m}^{-1}$. On the other hand, the increase of the $\mathrm{H}_{2} \mathrm{O}_{2}$ concentrations from $25 \mu \mathrm{M}$ provided reductions in the internal $\mathrm{CO}_{2}$ concentration, which was lower $\left(172.34 \mu \mathrm{mol} \mathrm{m}^{-2} \mathrm{~s}^{-1}\right)$ in plants submitted to $75 \mu \mathrm{M}$ of $\mathrm{H}_{2} \mathrm{O}_{2}$ and irrigated with $2.8 \mathrm{dS} \mathrm{m}^{-1}$ of water, corresponding to a reduction of $24.75 \%\left(56.68 \mu \mathrm{mol} \mathrm{m}^{-2} \mathrm{~s}^{-1}\right)$, when compared to plants with higher internal $\mathrm{CO}_{2}$ concentration.

The increase in the internal $\mathrm{CO}_{2}$ concentration observed in plants submitted to $25 \mu \mathrm{M}$ of $\mathrm{H}_{2} \mathrm{O}_{2}$ and irrigated with $1.4 \mathrm{dS} \mathrm{m}^{-1}$ of water was positive, since

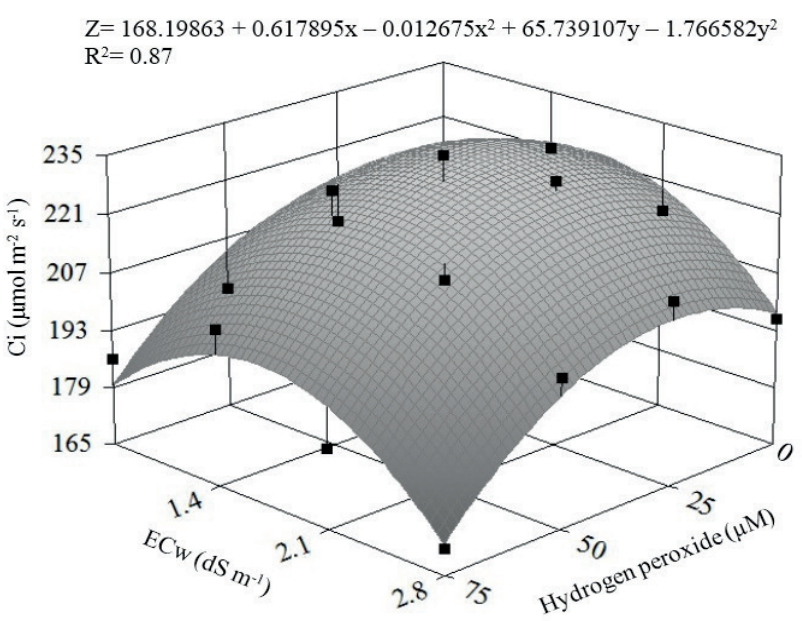

Figure 3. Internal $\mathrm{CO}_{2}$ concentration (Ci) of yellow passion fruit plants grown from seeds treated with different concentrations of hydrogen peroxide $\left(\mathrm{H}_{2} \mathrm{O}_{2}\right)$ and levels of irrigation water salinity ( $\mathrm{ECW})$, evaluated at 60 days after sowing ( $\mathrm{x}$ and $\mathrm{y}$ are the concentrations of $\mathrm{H}_{2} \mathrm{O}_{2}$ and $\mathrm{ECw}$, respectively). 
the $\mathrm{CO}_{2}$ assimilation rate (Figure 2B) showed an increase with the application of $25 \mu \mathrm{M}$ of $\mathrm{H}_{2} \mathrm{O}_{2}$. Thus, it is clear that the carbon into substomatic camera was used in the production of photoassimilates via photosynthetic process. The reductions in the internal $\mathrm{CO}_{2}$ concentration with the increase in the $\mathrm{ECw}$, in plants submitted to the treatment with $\mathrm{H}_{2} \mathrm{O}_{2}$ concentrations above $25 \mu \mathrm{M}$, probably occurred due to the lower diffusion of $\mathrm{CO}_{2}$ in the substomatal chamber, as a consequence of the stomatal closure (Silva et al. 2011, Oliveira et al. 2017).

The salt stress caused by the increase in the irrigation water electrical conductivity linearly reduced the instantaneous carboxylation efficiency of passion fruit plants (Figure 4A) by $18 \%$ per unit increase in the $\mathrm{ECW}$, i.e., when plants were subjected to irrigation with $2.8 \mathrm{dS} \mathrm{m}^{-1}$ of water the instantaneous carboxylation efficiency decreased by $43 \%\left\{0.0342\left[\left(\mu \mathrm{mol} \mathrm{m} \mathrm{s}^{-1}\right)\left(\mu \mathrm{mol} \mathrm{mol}^{-1}\right]^{-1}\right\}\right.$, if compared to the plants under irrigation with $0.7 \mathrm{dS} \mathrm{m}^{-1}$ of water.

Probably, the reduction in the instantaneous carboxylation efficiency is related to the dehydration of mesophyll cells, which consequently inhibits photosynthesis, thus affecting the carboxylation efficiency (Taiz \& Zeiger 2017). Sá et al. (2019) observed a reduction $(55.67 \%)$ in the instantaneous carboxylation efficiency in West Indian cherry plants cultivated under saline irrigation $\left(0.6 \mathrm{dS} \mathrm{m}^{-1}\right.$ to $3.8 \mathrm{dS} \mathrm{m}^{-1}$ ).

The instantaneous water-use efficiency was negatively affected by the irrigation water salinity and, according to the regression equation (Figure 4B), the linear model indicates that the highest instantaneous water-use efficiency $\left\{6.62\left[\left(\mu \mathrm{mol} \mathrm{m} \mathrm{m}^{-2} \mathrm{~s}^{-1}\right)\left(\mathrm{mol} \mathrm{m}^{-2} \mathrm{~s}^{-1} \text { of } \mathrm{H}_{2} \mathrm{O}\right)^{-1}\right]\right\}$ was obtained in plants cultivated with water of the lowest salinity level $\left(0.7 \mathrm{dS} \mathrm{m}^{-1}\right)$. By evaluating the behavior of this variable as a function of the increment in the water salinity, it was also possible to note a reduction of about $13.4 \%$ per unit increment in the $\mathrm{ECw}$, so it can be inferred that the increase in the irrigation water salinity directly affects the instantaneous wateruse efficiency of passion fruit plants. Similar results were obtained by Silva et al. (2019), in soursop plants (Annona muricata L.) under saline stress $\left(0.7 \mathrm{dS} \mathrm{m}^{-1}\right.$ to $3.5 \mathrm{dS} \mathrm{m}^{-1}$ ), where it was observed a reduction of $8.32 \%$ by unitary increase of the irrigation water electrical conductivity.

There was an interaction between the salinity levels and hydrogen peroxide concentrations for plant height and leaf area at 60 DAS (Table 2). The levels of irrigation water salinity significantly influenced $(\mathrm{p}<0.01)$ all the analyzed variables, except for the number of leaves. Additionally, the concentrations of hydrogen peroxide promoted a significant effect on the stem diameter and leaf area, at 60 DAS. Veloso et al. (2018), studying the effect of water salinity $\left(0.3 \mathrm{dS} \mathrm{m}^{-1}, 1.1 \mathrm{dS} \mathrm{m}^{-1}, 1.9 \mathrm{dS} \mathrm{m}^{-1}\right.$ and $\left.3.5 \mathrm{dS} \mathrm{m}^{-1}\right)$ on the production of soursop seedlings, cv. 'Morada Nova', also observed a significant effect of salinity on the growth variables plant height, stem diameter, number of leaves and leaf area. Gondim et al. (2013), in a study conducted with corn (Zea mays L.), found a significant effect of the interaction between salinity levels and $\mathrm{H}_{2} \mathrm{O}_{2}$ on plant growth.

At 45 DAS, as the irrigation water electrical conductivity increased, the plant height decreased by

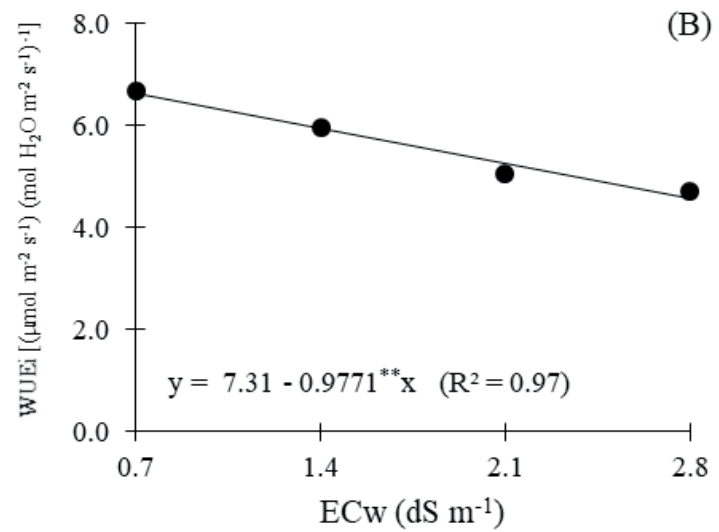

Figure 4. Instantaneous carboxylation efficiency - CEi (A) and instantaneous water-use efficiency - WUEi (B) of yellow passion fruit plants, as a function of the irrigation water salinity $(\mathrm{ECw})$, at 60 days after sowing. ** Significant at $1 \%$ of probability. 
Table 2. Summary of F-test significance ${ }^{1}$ in the analyses of variance for plant height (PH), stem diameter (SD), number of leaves (NL) and leaf area (LA) of passion fruit plants under saline water irrigation and exogenous application of hydrogen peroxide, at 45 and 60 days after sowing.

\begin{tabular}{|c|c|c|c|c|c|c|c|c|}
\hline \multirow{2}{*}{ Source of variation } & \multicolumn{2}{|c|}{$\mathrm{PH}$} & \multicolumn{2}{|c|}{$\mathrm{SD}$} & \multicolumn{2}{|c|}{$\mathrm{NL}$} & \multicolumn{2}{|c|}{$\mathrm{LA}$} \\
\hline & 45 & 60 & 45 & 60 & 45 & 60 & 45 & 60 \\
\hline Salinity levels (SL) & $* *$ & $* *$ & $* *$ & $* *$ & ns & ns & $* *$ & $* *$ \\
\hline Linear regression & $* *$ & $* *$ & $* *$ & $* *$ & ns & ns & $* *$ & $* *$ \\
\hline Quadratic regression & ns & ns & ns & ns & ns & ns & ns & ns \\
\hline Hydrogen peroxide $\left(\mathrm{H}_{2} \mathrm{O}_{2}\right)$ & ns & ns & ns & $* *$ & ns & ns & ns & $* *$ \\
\hline Linear regression & ns & ns & ns & $* *$ & ns & ns & ns & ns \\
\hline Quadratic regression & ns & ns & ns & ns & ns & ns & ns & $* *$ \\
\hline Interaction $\mathrm{SL} \times \mathrm{H}_{2} \mathrm{O}_{2}$ & ns & $*$ & ns & ns & ns & ns & ns & $* *$ \\
\hline Blocks & $\mathrm{ns}$ & ns & ns & ns & ns & ns & $\mathrm{ns}$ & ns \\
\hline $\mathrm{CV}(\%)$ & 11.9 & 8.1 & 14.4 & 7.9 & 16.1 & 9.4 & 19.3 & 17.3 \\
\hline
\end{tabular}

ns, ${ }^{*}$ and $* *$ : not significant $(\mathrm{p}>0.05)$, significant $(\mathrm{p}<0.05)$ and highly significant $(\mathrm{p}<0.01)$, respectively.

$8.6 \%$ per unit increase in salinity, i.e., a reduction of $19.3 \%(2.12 \mathrm{~cm})$ in the height of plants irrigated using water with the highest level of salinity $\left(2.8 \mathrm{dS} \mathrm{m}^{-1}\right)$, if compared to the lowest level $\left(0.7 \mathrm{dS} \mathrm{m}^{-1}\right)$ (Figure 5A). The reduction in plant height as a function of water salinity may be related to the water deficit induced by the osmotic effect, promoting stomatal closure and reduction in gas exchanges, and consequently reducing the absorption of water and nutrients by plants, what results in a lower growth (Lima et al. 2015). A similar result was reported by Araújo et al. (2013), who analyzed the height of passion fruit plants and observed a reduction $(28.42 \%)$ with the increase in the irrigation water salinity from $0.3 \mathrm{dS} \mathrm{m}^{-1}$ to $3.2 \mathrm{dS} \mathrm{m}^{-1}$.

The plant height of the yellow passion fruit was affected by the interaction between the studied factors (salinity levels $\times \mathrm{H}_{2} \mathrm{O}_{2}$ ) at 60 DAS and, according to the regression equation (Figure 5B), it was found that plants irrigated with $1.4 \mathrm{dS} \mathrm{m}^{-1}$ of

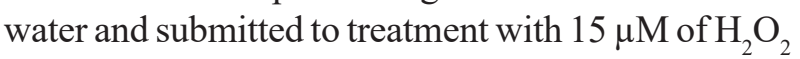
had the highest plant height $(40.2 \mathrm{~cm})$. However, there was a decrease in plant height when $\mathrm{H}_{2} \mathrm{O}_{2}$ concentrations above $15 \mu \mathrm{M}$ were used, regardless of the electrical conductivity of the irrigation water. The lowest plant height $(12.38 \mathrm{~cm})$ was obtained in plants irrigated with $2.8 \mathrm{dS} \mathrm{m}^{-1}$ of water and submitted to $75 \mu \mathrm{M}$ of $\mathrm{H}_{2} \mathrm{O}_{2}$, corresponding to a reduction of $69.2 \%(27.82 \mathrm{~cm})$, when compared to plants with a higher plant height.

As for the stem diameter of passion fruit, it was observed that irrigation using water with increasing levels of salinity caused reductions (Figure 6A), a decreasing linear effect on stem
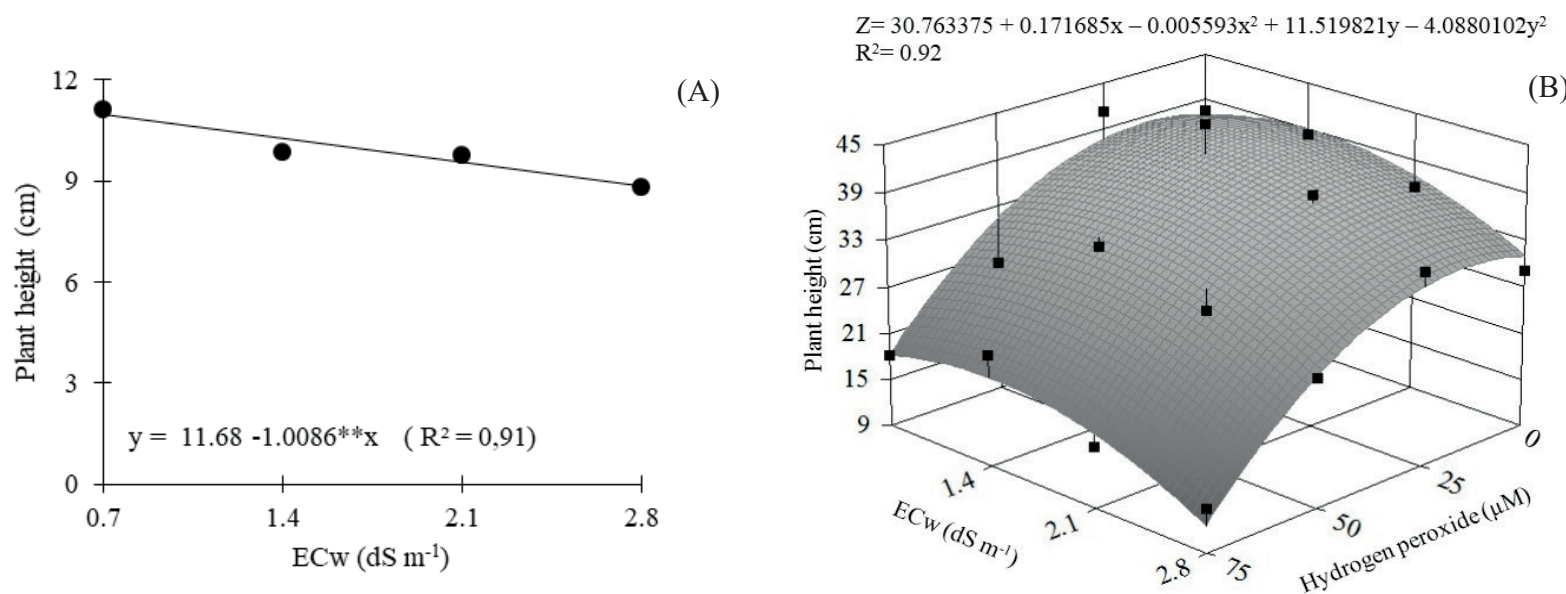

Figure 5. Plant height of yellow passion fruit, as a function of irrigation water salinity - ECw (A), at 45 days after sowing (DAS), and as a function of the interaction between $\mathrm{ECw}$ and hydrogen peroxide concentrations (B), at 60 DAS. ** Signficant value at $1 \%$ of probability. $\mathrm{B}, \mathrm{x}$ and $\mathrm{y}$ are the concentrations of $\mathrm{H}_{2} \mathrm{O}_{2}$ and $\mathrm{ECw}$, respectively. 
diameter, with reductions of the order of $8.3 \%$ and $11.6 \%$ per unit increase in the $\mathrm{ECW}$ at 45 and $60 \mathrm{DAS}$, respectively. The reduction of stem diameter with the increased irrigation water electrical conductivity may be associated with the reduction in the stomatal conductance observed in this study (Figure 1A), mainly due to the osmotic effect. Hydrogen peroxide had a positive effect on the stem diameter at 60 DAS (Figure 6B), with increments of $11.3 \%(0.47 \mathrm{~mm})$ at $75 \mu \mathrm{M}$ of $\mathrm{H}_{2} \mathrm{O}_{2}$, if compared to plants subjected to $0 \mu \mathrm{M}$ (control). The positive effect of hydrogen peroxide on the stem diameter may be attributed to the modulation of the physiological and metabolic processes, such as photosynthesis, proline accumulation and detoxification of reactive oxygen species, thus improving the plant growth and development (Hossain et al. 2015).

According to the regression equation (Figure 7A) relative to leaf area at $45 \mathrm{DAS}$, the linear model indicates a reduction of $13.1 \%$ per unit increase in the $\mathrm{ECW}$, i.e., a reduction of $36.7 \%$ $\left(80.42 \mathrm{~cm}^{2}\right)$ in plants irrigated using water with the highest salinity level $\left(2.8 \mathrm{dS} \mathrm{m}^{-1}\right)$, when compared to those under the lowest level $\left(0.7 \mathrm{dS} \mathrm{m}^{-1}\right)$. This result may be a consequence of adaptation mechanisms to the salt stress in plants, which reduce the transpiring surface. Thus, the reduction of leaf area under such conditions is relevant for maintaining a high water potential in the plant (Nobre et al. 2014).

By analyzing the interaction between the irrigation water electrical conductivity and the hydrogen
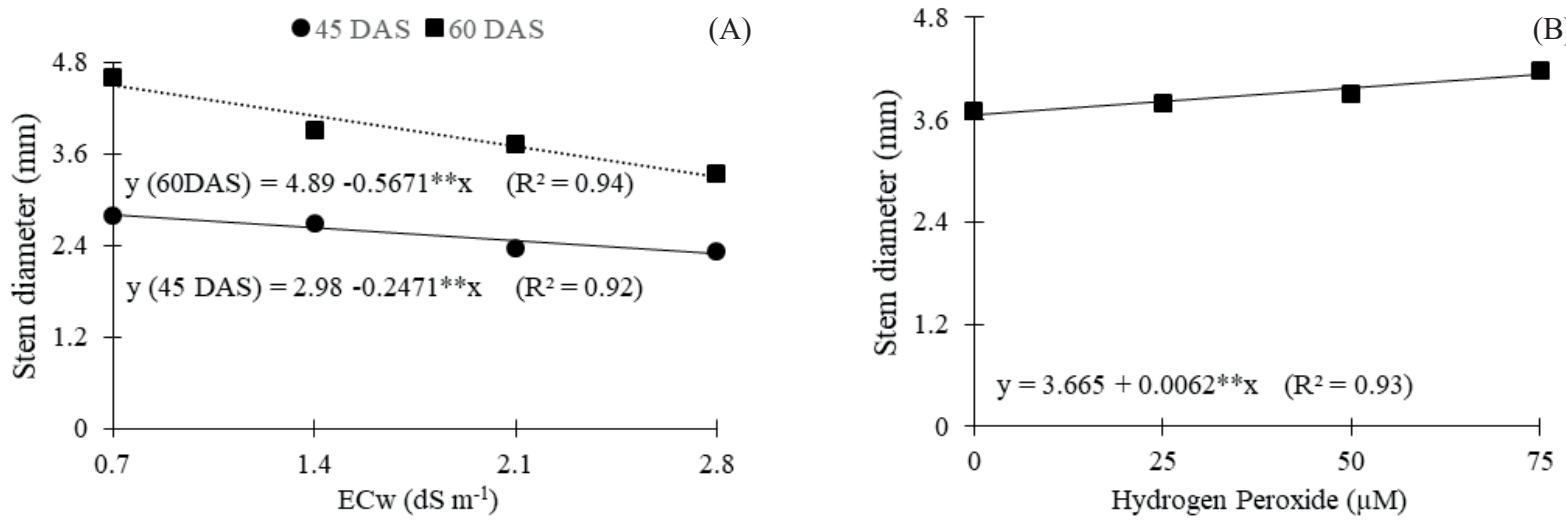

Figure 6. Stem diameter of yellow passion fruit plants, as a function of the irrigation water salinity - ECw (A), at 45 and 60 days after sowing (DAS), or as a function of hydrogen peroxide concentrations (B), at 45 DAS. ** Signficant at $1 \%$ of probability.
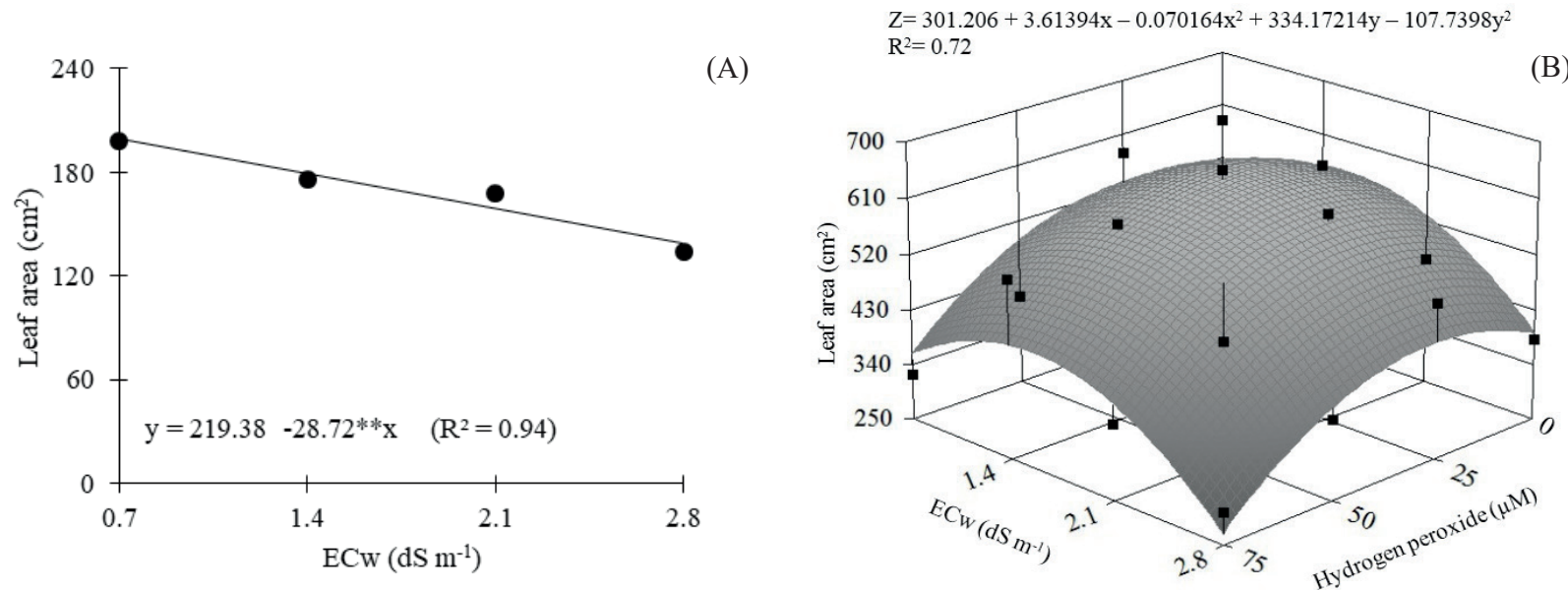

Figure 7. Leaf area of passion fruit plants, as a function of irrigation water salinity - ECw (A), at 45 days after sowing (DAS), and as a function of the interaction between the $\mathrm{ECW}$ and hydrogen peroxide concentration (B), at 60 DAS. ** Significant value at $1 \%$ of probability. $\mathrm{B}$, $\mathrm{x}$ and $\mathrm{y}$ are the concentrations of $\mathrm{H}_{2} \mathrm{O}_{2}$ and $\mathrm{ECw}$, respectively. 
peroxide concentrations on the leaf area of passion fruit plants at 60 DAS (Figure 7B), it was verified, based on the regression equation, that the maximum leaf area $\left(605.644 \mathrm{~cm}^{2}\right)$ was obtained in plants submitted to the treatment with $25 \mu \mathrm{M}$ of $\mathrm{H}_{2} \mathrm{O}_{2}$ and irrigated with $1.4 \mathrm{dS} \mathrm{m}^{-1}$ of water. The lowest leaf area $\left(260.28 \mathrm{~cm}^{2}\right)$ was obtained in plants submitted to $75 \mu \mathrm{M}$ of $\mathrm{H}_{2} \mathrm{O}_{2}$ and irrigated with $2.8 \mathrm{dS} \mathrm{m}^{-1}$ of water, corresponding to a $57.02 \%$ reduction $\left(345.36 \mathrm{~cm}^{2}\right)$, when compared to plants with a larger leaf area. The leaf area increase observed at the concentration of $25 \mu \mathrm{M}$ may be associated with a higher synthesis of organic solutes, which reduced the cell osmotic potential and favored the absorption of water and nutrients (Carvalho et al. 2011, Ge et al. 2015).

\section{CONCLUSIONS}

1. Irrigation water with electrical conductivity above $0.7 \mathrm{dS} \mathrm{m}^{-1}$ negatively affects the gas exchanges and growth of passion fruit, and stomatal conductance and leaf area are the most sensitive variables to salt stress;

2. The reduction in stomatal opening is a limiting factor for the $\mathrm{CO}_{2}$ diffusion in the substomatic chamber, in passion fruit plants;

3. Hydrogen peroxide at $25 \mu \mathrm{M}$ mitigates the negative effects of $1.4 \mathrm{dS} \mathrm{m}^{-1}$ of water salinity on transpiration, $\mathrm{CO}_{2}$ assimilation rate, internal $\mathrm{CO}_{2}$ concentration, plant height and leaf area;

4. Regarding the salt tolerance level, the yellow passion fruit may be classified as sensitive to saline stress, with a water salinity threshold of $0.7 \mathrm{dS} \mathrm{m}^{-1}$.

\section{REFERENCES}

ARAÚJO, W. L.; SOUSA, J. R. M.; SOUSA JUNIOR, J. R.; SILVA, S. S.; ALEIXO, D. L., PEREIRA, E. B. Produção de mudas de maracujazeiro-amarelo irrigadas com água salina. Agropecuária Científica no Semiárido, v. 9, n. 4, p. 15-19, 2013.

BAXTER, A.; MITTLER, R.; SUZUKI, N. EROS as key players in plant stress signalling. Journal of Experimental Botany, v. 65, n. 5, p. 1229-1240, 2014.

CARVALHO, F. E. L.; LOBO, A. K. M.; BONIFACIO, A.; MARTINS, M. O.; LIMA NETO, M. C.; SILVEIRA, J. A. G. Aclimatação ao estresse salino em plantas de arroz induzida pelo pré-tratamento com $\mathrm{H}_{2} \mathrm{O}_{2}$. Revista Brasileira de Engenharia Agrícola e Ambiental, v. 15, n. 4, p. 416-423, 2011.
CAVALCANTE, L. F.; DIAS, T. J.; NASCIMENTO, R. D.; FREIRE, J. D. Clorofila e carotenoides em maracujazeiro-amarelo irrigado com águas salinas no solo com biofertilizante bovino. Revista Brasileira de Fruticultura, v. 33, supl. 1, p. 699-705, 2011.

CAVALCANTE, L. F.; SANTOS, J. B.; SANTOS, C. J. O.; FEITOSA FILHO, J. C.; LIMA, E. M.; CAVALCANTE, I. H. L. Germinação de sementes e crescimento inicial de maracujazeiros irrigados com água salina em diferentes volumes de substrato. Revista Brasileira de Fruticultura, v. 24, n. 3, p. 748-751, 2002.

FERREIRA, D. F. Sisvar: a guide for its bootstrap procedures in multiple comparisons. Ciência e Agrotecnologia, v. 38, n. 2, p. 109-112, 2014.

FREIRE, J. L.; DIAS, T. J.; CAVALCANTE, L. F.; FERNANDES, P. D.; LIMA NETO, A. J. Rendimento quântico e trocas gasosas em maracujazeiro amarelo sob salinidade hídrica, biofertilização e cobertura morta. Revista Ciência Agronômica, v. 45, n. 1, p. 82-91, 2014.

GE, X. M.; CAI, H. L.; LEI, X.; ZHOU, X.; YUE, M.; HE, J. M. Heterotrimeric G protein mediates ethyleneinduced stomatal closure via hydrogen peroxide synthesis in Arabidopsis. The Plant Journal, v. 82, n. 1, p. 138-150, 2015.

GONDIM, F. A.; GOMES FILHO, E.; MARQUES, E. C.; PRISCO, J. T. Efeitos do $\mathrm{H}_{2} \mathrm{O}_{2}$ no crescimento e acúmulo de solutos em plantas de milho sob estresse salino. Revista Ciência Agronômica, v. 42, n. 2, p. 373-38, 2011.

GONDIM, F. A.; MIRANDA, R. D. S.; GOMES FILHO, E.; PRISCO, J. T. Enhanced salt tolerance in maize plants induced by $\mathrm{H}_{2} \mathrm{O}_{2}$ leaf spraying is associated with improved gas exchange rather than with non-enzymatic antioxidant system. Theoretical and Experimental Plant Physiology, v. 25 , n. 4 , p. 251-260, 2013.

HOSSAIN, M. A.; BHATTACHARJEE, S.; ARMIN, S. M.; QUIAN, P.; XIN, W.; LI, H. Y.; TRAN, L. S. P.; Hydrogen peroxide priming modulates abiotic oxidative stress tolerance: insights from ROS detoxification and scavenging. Frontiers in Plant Science, v. 6, n. 1, p. 1-19, 2015.

INSTITUTO BRASILEIRO DE GEOGRAFIA E ESTATÍSTICA (IBGE). Anuário estatístico do Brasil: Sistema IBGE de Recuperação Automática (SIDRA). Rio de Janeiro: IBGE/SIDRA, 2017.

JAIMEZ, R. E.; RADA, F.; GARCÍA NUNEZ, C.; AZÓCAR, A. Seasonal variations in leaf gas exchange of platain cv. Hartón (Musa AAB) under different soil water conditions in a humid tropical region. Scientia Horticulturae, v. 104, n. 1, p. 79-89, 2005.

LARCHER, W. Ecofisiologia vegetal. São Carlos: Rima Artes e Textos, 2006. 
LIMA, G. S.; NOBRE, R. G.; GHEYI, H. R.; SOARES, L. A. A.; SILVA, A. O. Physiology, growth and yield of castor bean under salt stress and nitrogen doses in phenophases. Idesia, v. 32, n. 3, p. 91-99, 2014.

LIMA, L. A.; OLIVEIRA, F. D. A.; CASSIA, R. A.; LINHARES, P. S. F.; MEDEIROS, A. M. A.; BEZERRA, F. M. S. Tolerância da berinjela à salinidade da água de irrigação. Revista Agroambiente, v. 9, n. 1, p. 27-34, 2015.

MEDEIROS, J. F. de. Qualidade de água de irrigação e evolução da salinidade nas propriedades assistidas pelo GAT nos Estados de RN, PB e CE. 1993. Dissertação (Mestrado em Engenharia Agrícola) - Universidade Federal da Paraíba, Campina Grande, 1992.

MEDEIROS, S. A. S.; CAVALCANTE, L. F.; BEZERRA, M. A. F.; NASCIMENTO, J. A. M.; BEZERRA, F. T. C.; PRAZERES, S. S. Água salina e biofertilizante de esterco bovino na formação e qualidade de mudas de maracujazeiro amarelo. Irriga, v. 21, n. 4, p. 779-795, 2016.

MUNNS, R.; TESTER, M. Mechanisms of salinity tolerance. Anual Review of Plant Biology, v. 59, n. 1, p. 651-681, 2008.

NOBRE, R. G.; LIMA, G. S.; GHEYI, H, R.; SOARES, L. A. A.; SILVA, A. O. Crescimento, consumo e eficiência do uso da água pela mamoneira sob estresse salino e nitrogênio. Revista Caatinga, v. 27, n. 2, p. 148-158, 2014.

NOVAIS, R. F.; NEVES, J. C. L.; BARROS, N. F. Ensaio em ambiente controlado. In: OLIVEIRA, A. J. (ed.). Métodos de pesquisa em fertilidade do solo. Brasília, DF: Embrapa-SEA, 1991. p. 189-253.

OLIVEIRA, M. G. Efeito do pré-tratamento foliar com $\mathrm{H}_{2} \mathrm{O}_{2}$ sobre o proteoma e enzimas antioxidantes em plantas de feijão-de-corda submetidas ao estresse salino. 2016. Tese (Doutorado em Bioquímica) - Universidade Federal do Ceará, Fortaleza, 2016.

OLIVEIRA, W. J. D.; SOUZA, E. R. D.; CUNHA, J. C.; SILVA, E. F. F.; VELOSO, V. D. L. Leaf gas exchange in cowpea and $\mathrm{CO}_{2}$ efflux in soil irrigated with saline water. Revista Brasileira de Engenharia Agrícola e Ambiental, v. 21, n. 1, p. 32-37, 2017.
PANNGOM, K.; CHUESAARD, T.; TAMCHAN, N.; JIWCHAN, T.; SRIKONGSRITONG, K.; PARK, G. Comparative assessment for the effects of reactive species on seed germination, growth and metabolisms of vegetables. Scientia Horticulturae, v. 227, n. 1, p. 85-91, 2018 .

RHOADES, J. D.; KANDIAH, A.; MASHALI, A. M. Uso de águas salinas para produção agrícola. Campina Grande: Ed. UFPB, 2000.

SÁ, F. V. S.; GHEYI, H. R.; LIMA, G. S.; PAIVA, E. P.; SILVA, L. A.; MOREIRA, R. C. L.; FERNANDES, P. D.; DIAS, A. S. Ecophysiology of West Indian cherry irrigated with saline water under phosphorus and nitrogen doses. Bioscience Journal, v. 35, n. 1, p. 211-221, 2019.

SAVVIDES, A.; ALI, S.; TESTER, M.; FOTOPOULOS, V. Chemical priming of plants against multiple abiotic stresses: mission possible? Trends in Plant Science, v. 21, n. 1, p. 329-340, 2016.

SILVA, A. A. R.; LIMA, G. S.; AZEVEDO, C. A. V.; VELOSO, L. L. S. A.; GHEYI, H. R.; SOARES, L. A. A. Salt stress and exogenous application of hydrogen peroxide on photosynthetic parameters of soursop. Revista Brasileira de Engenharia Agrícola e Ambiental, v. 23, n. 4, p. 257-263, 2019.

SILVA, E. N.; RIBEIRO, R. V.; SILVA, S. L. F.; VIÉGAS, R. A.; SILVEIRA, J. A. G. Salt stress induced damages on the photosynthesis of physic nut young plants. Scientia Agricola, v. 68, n. 1, p. 62-68, 2011.

TAIZ, L.; ZEIGER, E. Fisiologia vegetal. 6. ed. Porto Alegre: Artmed, 2017.

TEIXEIRA, P. C.; DONAGEMA, G. K.; FORTANA, A.; TEIXEIRA, W. G. Manual de métodos de análise de solo. 3. ed. Brasília, DF: Embrapa Solos, 2011.

VELOSO, L. L. S. A.; NOBRE, R. G.; PÁDUA, L. S.; GHEYI, H, R.; CAVALCANTE, I. T. S.; ARAUJO, E. B. G.; SILVA, W. L. Formation of soursop seedlings irrigated using waters with different salinity levels and nitrogen fertilization. Bioscience Journal, v. 34, n. 6, p. 151-160, 2018. 